\title{
Antiviral Activity of Diterpenes From Canistrocarpus Cervicornis against Human Herpesvirus 1 and Bovine Herpesvirus 5
}

Robson dos Santos Souza Marinho ${ }^{1}$, Maria Clara Rodrigues Vieira ${ }^{1,2}$, Caroline de Souza Barros ${ }^{2}$, Claudio Cesar Cirne-Santos ${ }^{2}$, Jose Paulo Gagliardi Leite ${ }^{3}$, Valéria Laneuville Teixeira ${ }^{4,5}$, Izabel Christina Nunes de Palmer Paixao ${ }^{2}$ and Ana Maria Viana Pinto ${ }^{1 *}$

${ }^{1}$ Department of Microbiology and Parasitology, Fluminense Federal University (UFF), Brazil

${ }^{2}$ Department of Cellular and Molecular Biology, Laboratory of Molecular Virology Biology Institute, Fluminense Federal University (UFF), Brazil

${ }^{3}$ Laboratory of Comparative and Environmental Virology, Oswaldo Cruz Foundation, Brazil.

${ }^{4}$ Department of Marine Biology, Marine Algae Natural Products Laboratory (ALGAMAR), Institute of Biology, Fluminense Federal University, Brazil.

${ }^{5}$ Algae Biology and Taxonomy Laboratory (LABIOTAL), Federal University of Rio de Janeiro State, Brazil.

*Corresponding author: Ana Maria Viana Pinto, Department of Microbiology and Parasitology. Federal Fluminense University, Hernani Melo Street, Brazil.
Received Date: October 16, 2019

Published Date: October 31, 2019

\begin{abstract}
Human alphaherpesvirus 1 is an etiologic agent of infection endemic in the world transmitted by oral to oral oral-genital contact, from mothers causing neonatal herpes and complications such encephalitis or ocular disease. Bovine alphaherpesvirus 5 is an important agent of meningoencephalitis in cattle and has been identified in outbreaks of neurological disease in bovine in several Brazilian States. The aims of this work were to evaluate cytotoxic effect, antiviral properties of the diterpenes 1 and 2 isolated from Canistrocarpus cervicornis. The results of cytotoxic effects in VERO cell showed diterpene 1 more cytotoxic in MTT and Neutral red assay than diterpene 2. The low value to effective concentration required to diterpenes achieve $50 \%$ protection to Vero cell showed to diterpene 1 high selectivity index. Both compounds were not cytotoxic to MDBK cell, but they are not able to inhibit Bovine alphaherpesvirus 5 (BoHV-5RJ42/01) replication. Diterpenes 1 and 2 interacted directly with Human alphaherpesvirus 1 (KOS) and BoHV-5RJ42/01 reducing their infectivity on VERO and MDBK cells but they did not inhibit KOS and BoHV5RJ42/01 attachment and penetration in Vero and MDBK cells respectively.
\end{abstract}

Keywords: Canistrocarpus cervicornis; Diterpenes; Human alphaherpesvirus 1; KOS, Bovine alphaherpesvirus 5 BoHV-5; Antiviral

\section{Introduction}

Human alphaherpesvirus 1 and Bovine alphaherpesvirus 5 (BoHV-5) are members of the family Herpesviridae, subfamily Alphaherpesvirinae. Human alphaherpesvirus 1 (HHV-1) is including in genus Simplex distributed worldwide [1]. The frequency of seropositive individuals is high, ranging from $50 \%$ to over $80 \%$ [2]. The Human alphaherpesvirus 1 transmission occurs by direct contact person to person and more likely if blisters or lesions are present. Adolescents and adults frequently get exposed by skin contact but may get exposure by kissing or sexual contact [2]. HHV1 infection can occur at different sites of the body. Primary disease is characterized by sore throat, ulcerative and vesicular lesions, gingivostomatitis lymphadenopathy with fever and malaise. Rare, keratoconjunctivitis, encephalitis, and disseminated infections are severe complications of HHV-1 infection [2].

Bovine alphaherpesviruses 5 (BoHV-5) is belonging to the genus Varicellovirus [1], and has been associated with fatal meningoencephalitis in cattle [3] and it has been reported in Australia [4], Argentina [3] and Brazil [5,6] as etiologic agent of neurological disease. BoHV-5 affects mainly but not exclusively young animals. Furthermore, it has been identified from the 
respiratory [7], genital tracts [8]. BoHV-5 has been described in cryopreserved semen (8) and after experimental infection in oocytes, embryos and inside spermatozoids $[9,10]$.

Bioactive compounds from marine seaweed have been studied to understand their biological effects and application in drugs development. Compounds from marine algae have revealed healthpromoting effects, including anti-oxidative, anti-inflammatory, antimicrobial, anti-cancer and antiviral effects [11]. Canistrocarpus cervicornis (Kutzing) De Paula and De Clerck is important and abundant seaweed of Brazilian coast [12]. From this seaweed was described the isolation of many dolastanes and secodolastanes diterpenes [13-17]. Since then a variety of biological activities of these diterpenes have been published [18-21], including activity against Human alphaherpesvirus 1 [22] and against human immunodeficiency virus 1 [23]. Our purposes in this work were to evaluate the cytotoxicity effect and antiviral activity of two diterpenes purified from crude extract from C. cervicornis and to determine the activities of these compounds on HHV-1 KOS and BoHV-5RJ42/01 replication.

\section{Materials and Methods}

\section{Algal collection}

Specimens of brown seaweed C. cervicornis (Kützing) De Paula and De Clerck were collected at Praia do Velho in Angra dos Reis, in the south of Rio de Janeiro State, Brazil (lat. $23^{\circ} 01^{\prime} \mathrm{S}$, long. $44^{\circ}$ $00^{\prime} W$ ). Voucher specimens (HRJ 10754) were deposited in the Herbarium of the Universidade do Estado do Rio de Janeiro (UERJ). The seaweeds were washed with local sea water and separated from sediments, epiphytes, and other associated organisms.

Chemical extraction of diterpene 1 (4R,7R,14S)$4 \alpha, 7 \alpha$-diacetoxy-14-hydroxydolast-1(15),8-diene) and diterpene $2(4 R, 9 S, 14 S)-4 \alpha$-acetoxy-9 $9,14 \alpha-$ dihidroxydolast-1(15),7-diene) from C. cervicornis

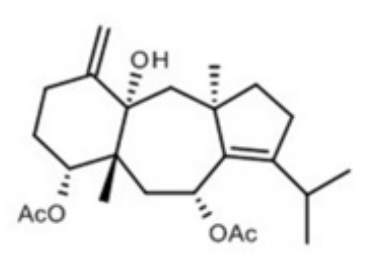

1

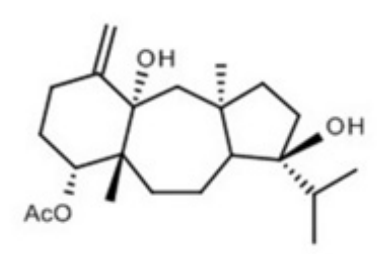

2
Figure 1: Chemical structures of compounds 1 and 2 derived from Canistrocarpus cervicornis.

In order to prepare crude extract air-dried seaweeds were exhaustively extracted with $\mathrm{CH}_{2} \mathrm{Cl}_{2}$ at room temperature. The extract was evaporated under reduced pressure, yielding a brownish residue. The crude extract was acetylated as described previously by our group [23]. The acetylated extract was subjected to silica gel chromatography (3 x $40 \mathrm{~cm}$ ) eluted with $100 \%$ n-hexane to $100 \%$ EtOAc, in steps of $10 \%$ and $100 \mathrm{~mL}$, from which 49 fractions were obtained. The fractionation was monitored by thin layer chromatography and spots of diterpenes were detected as pink-colored spots after heating the plated specimens at $100^{\circ} \mathrm{C}$ for 3 minutes. The fraction 9 yielded the dolastane diterpene 1 . The acetylation reaction and silica gel chromatography were repeated on another aliquot of crude extract, from which 44 fractions were obtained. The fractions 26,27 , and 28 yielded the dolastane diterpene 2 . The structures of the diterpenes were assigned by comparison of physical and spectroscopic data with reported values [15] (Figure 1).

\section{Cells and virus and acyclovir}

African green monkey kidney VERO-ATCCCCL81 originally obtained from ATCC and Madin-Darbin bovine kidney (MDBK) cell lineage, originally obtained from ATCC (CCL-22) were grown and maintained in Eagle's minimum essential medium (EMEM) containing $292 \mu \mathrm{g} / \mathrm{mL}$ of L-glutamine, $50 \mu \mathrm{g} / \mathrm{mL}$ of gentamicin and supplemented with $2-5 \%$ heated inactivated certified fetal calf serum (Invitrogen). Overlay medium for plaque assay consisted of EMEM 2 x plus in agarose 2\% (1:1). Human alphaherpesvirus 1 (HHV-1 KOS) stocks were prepared by infecting subconfluent monolayers of Vero cells at a multiplicity of infection of the 1 MOI. Infected cells were incubated at $37{ }^{\circ} \mathrm{C}$ under a $5 \% \mathrm{CO}_{2}$ humidified atmosphere and harvested when total cytopathic effect was observed. After three freeze-thaw cycles, cell debris was removed by low-speed centrifugation $\left(2,000 \mathrm{x}\right.$ g at $4^{\circ} \mathrm{C}$ for $\left.15 \mathrm{~min}\right)$ and titers were determined by plaque assays on Vero cells (24) and expressed as plaque forming units (P.F.U per mL-1). Aliquots of HHV-1 KOS were stored at $-70^{\circ} \mathrm{C}$ until use. Bovine alphaherpesvirus 5 (BoHV5RJ42/01) was isolated and characterized previously (Pinto et al. 2015). Virus stocks were propagated in MDBK cells, and the virus titer was determined by plaque assay (PA) (24). The title of the virus was expressed as plaque-forming units (PFU per mL-1). Acyclovir (ACV) used as standard compound purchase from Sigma-Aldrich. All compounds were dissolved in dimetylsulphoxide (DMSO) to obtain stock solutions of $50 \mathrm{mM}$ then diluted in the culture medium without serum to obtain the desired compound's concentration before use. The final concentration of DMSO was $<0.1 \%$.

\section{Cytotoxicity assay}

The cytotoxic effect of seaweed diterpenes 1, 2 and acyclovir was assayed by three methodologies (3-(4,5-dimethylthiazol2yl)-2,5diphenyl tetrazolium bromide (MTT) (25), neutral red (NR) (26) and violet crystal (VC) (27) in Vero and MDBK cell with some modification. Vero and MDBK cells at density of $3 \times 10^{3}$ were grown in 96 well microplates at $37{ }^{\circ} \mathrm{C}$ under a $5 \% \mathrm{CO}_{2}$ humidified atmosphere. After 24 hours culture media were replaced with EMEM containing different concentrations of diterpene 1 and 2 and standard compound acyclovir $(12.5,25,50,100$ and $200 \mu \mathrm{M})$ in triplicate. Vero and MDBK cell untreated were used as control. After 72 hours of incubation the supernatants were discarded, and plates separated in three groups for revelation.

In the first group of the plates was added MTT $(100 \mu \mathrm{L}$ of 1 mg mL-1 in EMEM) in each well following reincubation for $3 \mathrm{~h} 37$ ${ }^{\circ} \mathrm{C}$ under a $5 \% \mathrm{CO}_{2}$ humidified atmosphere. Then the medium was 
discarded and DMSO $(100 \mu \mathrm{L})$ added before a further incubation for $30 \mathrm{~min}$.

For neutral red (NR) cytotoxicity assay revelation $100 \mu \mathrm{L}$ of neutral red $0.01 \%$ were added in all plates wells and after $3 \mathrm{~h}$ at 37 ${ }^{\circ} \mathrm{C}$ under a $5 \% \mathrm{CO}_{2}$ humidified atmosphere then supernatants were discarded and cell fixed with formaldehyde [100 $\mu \mathrm{L}$ of $1 \mathrm{mg} \mathrm{mL}-1$ in PBS (NaCl $130 \mathrm{mM}$; KCl2 mM; $\mathrm{Na}_{2} \mathrm{HPO}_{4} 2 \mathrm{H}_{2} \mathrm{O}_{6} \mathrm{mM} ; \mathrm{K}_{2} \mathrm{HPO}_{4} 1 \mathrm{mM}$, $\mathrm{pH}$ 7.2)] and after reincubation for $15 \mathrm{~min}$ the formaldehyde was removed and the neutral red was extracted from cell with $100 \mu \mathrm{L}$ of the acetic acid $1 \%$ in methanol 50\%.

In the third sets of the plates was added violet crystal (VC) $0.5 \%$ in acetic acid $30 \%(100 \mu \mathrm{L})$. The plates were maintained for $30 \mathrm{~min}$ at room temperature. Then cells were washed with water and dried at $37^{\circ} \mathrm{C}$ following elution of $\mathrm{VC}$ by addition of methanol P.A $(100 \mu \mathrm{L})$. Finally, optical densities of all three experiments were measured at $520 \mathrm{~nm}$ in microplate reader and results were expressed as the $50 \%$ cytotoxic concentration $\left(\mathrm{CC}_{50}\right)$. The compound concentration required to reduce the optical density in relation to the cell control was calculated by a linear regression analysis.

\section{Screening of antiviral activity of compounds by plaque reduction assay}

An antiviral screening test was performed in Vero and MDBK cells grown in 24 well microplates were inoculated with 200 P.F.U of the HHV-1KOS and BoHV-5RJ42/01 respectively as described previously (24) with some modifications (28). After one hour for virus adsorption at $37{ }^{\circ} \mathrm{C}$ with a $5 \% \mathrm{CO}_{2}$ atmosphere the inoculum was discarded for addition of the differents concentration of diterpenes 1, 2 and ACV $(12.5,25,50$ and $100 \mu \mathrm{M})$. The plates were reincubated for $72 \mathrm{~h}$ at $37{ }^{\circ} \mathrm{C}$ with a $5 \% \mathrm{CO}_{2}$ atmosphere. Then cell monolayer was fixed and stained with crystal violet $(1 \%)$ in formalin (10\%). The antiviral concentration of compounds of $50 \%$ effectiveness $\left(\mathrm{EC}_{50}\right)$ was defined as the concentration required reducing plaque number by $50 \%$ in the treated cells compared to untreated ones by the formula:

Percent of inhibition $(\%)=$ Number total of control plaques Number total of tested plaques $\mathrm{x} 100$

Number of total of control plaques

\section{Virus inactivation of infectivity assay}

In brief HHV-1KOS and BoHV-5RJ42/01 suspension containing $1 \times 10^{4}$ P.F.U mL- 1 were mixed with $12.5,25$ and $50 \mu \mathrm{M}$ of compounds and kept at room temperature $\left(24^{\circ} \mathrm{C}\right)$ for $1 \mathrm{~h}$. Meanwhile, control of untreated virus suspension was performed in the same conditions. After that they were diluted, and residual infectivity was determined by plaque assay as described previously [24].

\section{Inhibition of virus attachment assay in pretreated cell and unpretreated cell}

Virion attachment assay was performed as described earlier [24] with some modifications [28]. Vero and MDBK cells monolayers grown in 24 well microplates were pre-chilled at $4^{\circ} \mathrm{C}$ for $1 \mathrm{~h}$. The medium was aspirated and a set of the monolayers were inoculated with 200 P.F.U of HHV-1 KOS or BoHV-5RJ42/01 after pre-treatment with compounds (12.5 and $50 \mu \mathrm{M})$ for $1 \mathrm{~h}$ at $4^{\circ} \mathrm{C}$. Other set of monolayers previously chilled were inoculated with HHV-1 KOS or BoHV-5RJ42/01 in the presence or absence of differents concentrations of diterpene 1, diterpene 2 and ACV (12.5 and $50 \mu \mathrm{M}$ ). Next, all plates were reincubated for $3 \mathrm{~h}$ at $4{ }^{\circ} \mathrm{C}$. Then cell monolayers were washed three times with MEM-E and covered with overlaid medium and reincubated. After $72 \mathrm{~h}$ cell monolayers were stained and the attachment-inhibition percentage was calculated as described in the item: Screening of antiviral activity by plaque reduction assay.

\section{Inhibition of virus penetration assay}

The HHV-1 KOS and BoHV-5RJ42/01 internalization assay in Vero or MDBK cells was conducted as described Cheng et al. 2004 with some modifications [28]. Vero and MDBK cell were grown in 24-well plates for $24 \mathrm{~h}$ and pre-chilled at $4{ }^{\circ} \mathrm{C}$ for $1 \mathrm{~h}$. Vero or MDBK cell monolayers were inoculated with $200 \mathrm{PFU}$ of HHV-1 KOS and BoHV-5RJ42/01 respectively and maintained at $4{ }^{\circ} \mathrm{C}$ for $3 \mathrm{~h}$ for virus attachment. The cells were then washed three times with E-MEM and preincubated with a medium containing different concentrations of diterpene 1 , diterpene 2, and acyclovir (12.5, 25,50 and $100 \mu \mathrm{M}$ ) for $20 \mathrm{~min}$ at $4{ }^{\circ} \mathrm{C}$. The temperature was then rapidly increased by transfer to $37^{\circ} \mathrm{C}$. Prior to and at various times after the temperature increase $(0,15,30,45$, and $60 \mathrm{~min}$.), the monolayers were then treated with PBS, pH 3 (10 mM anhydrous sodium dihydrogen phosphate in water and adjust to $\mathrm{pH}=3.0$ with $100 \mathrm{mM}$ phosphoric acid) for $1 \mathrm{~min}$ and immediately neutralized with PBS, pH 11 (10mM anhydrous sodium dihydrogen phosphate in water and adjust to $\mathrm{pH}=11$ with $100 \mathrm{mM}$ phosphoric acid), and covered with overlay medium. After another reincubation for $72 \mathrm{~h}$ at $37^{\circ} \mathrm{C}$ with a $5 \% \mathrm{CO}_{2}$ atmosphere, the monolayers were stained, the percentage of inhibition of penetration was determined using the formula described in the section (Screening of antiviral activity of compounds by plaque reduction assay).

\section{Statistical analysis}

All of the data shown represents the mean $\pm S D$ of triplicate experiments using three independent determinations. All of the statistical analyses were performed using Excel for Windows, and $\mathrm{p}$ values equal to or less than 0.05 were considered statistically significant by Student's t-test.

\section{Result}

The acetylation of the crude extract increases the amount and stability of the most abundant diterpenes by replacing the secondary hydroxyl groups by acetyl groups (diterpenes 1 and 2). The treatment of Vero and MDBK cell with different concentrations of Diterpene 1, diterpene 2 and ACV showed different degree of cytotoxicity after $72 \mathrm{~h}$ of the incubation (Table 1). By combining of three methodologies, neutral red (NR), MTT and crystal violet staining assay the $\mathrm{CC}_{50}$ results showed that both compounds (diterpene 1 and diterpene 2) were a little more cytotoxic to Vero 
than to MDBK cell by MTT assay and diterpene 1 was the most cytotoxic by neutral red assay but not significantly. All compounds did not interfere in the integrity of cell DNA. Table 1 also shows diterpenes 1 and 2 inhibit HHV- 1 KOS production in Vero cell $\left(\mathrm{EC}_{50}\right)$. On the other hand, they did not block the BoHV-5RJ42/01 production in MDBK cell in the screening of antiviral activity assay (Table 1). According to $\mathrm{EC}_{50}$ and SI results the diterpene 1 inhibit HHV-1 KOS more efficiently than diterpene 2. but both compounds did not inhibit BoHV-5RJ42/01yield (Table 1).

Table 1: Cytotoxicity, antiviral activity of C. cervicornis diterpene 1 and diterpene 2 and acyclovir against HHV-1 KOS and BoHV-5RJ42/01 and selectivity indexes effect on Vero and MDBK cells.

\begin{tabular}{|c|c|c|c|c|c|c|c|}
\hline \multirow{2}{*}{$\begin{array}{l}\text { Standard compound and } \\
\text { diterpenes from } \\
\text { C. cervicornis }\end{array}$} & \multicolumn{3}{|c|}{$\mathrm{CC}_{50}$ in Vero cell* and MDBK cell $\uparrow(\mu \mathrm{M})$} & \multirow{2}{*}{$\begin{array}{l}\text { HHV-1* and BoHV-5 } \dagger \\
\mathrm{EC}_{50}(\mu \mathrm{M})\end{array}$} & \multicolumn{3}{|c|}{ SI (HHV-1* and BoHV-5†) } \\
\hline & MTT & NR & VC & & MTT & NR & VC \\
\hline Acyclovir & $\begin{array}{c}1168 \pm 3^{*} 1214 \\
\pm 12 \dagger\end{array}$ & $\begin{aligned} 998 & \pm 5 * 1132 \\
& \pm 5 \dagger\end{aligned}$ & $\begin{array}{c}1010 \pm 7 * 828 \\
\pm 7.9 \dagger\end{array}$ & $9.7 \pm 3.1 * 166 \pm 6.2 \dagger$ & $120 * 6 \dagger$ & $101 * 7 \dagger$ & $104 * 5.6 \dagger$ \\
\hline Diterpene 1 & $\begin{aligned} 650 & \pm 7.3 * 1214 \\
& \pm 12 \dagger\end{aligned}$ & $\begin{array}{c}781 \pm 9.5^{*} 1171 \\
\quad \pm 8.5 \dagger\end{array}$ & $\begin{array}{l}1201 \pm \\
11.1 * 1113 \pm \\
8.9 \dagger\end{array}$ & $6.25 \pm 7.5^{*} \mathrm{~N} \dagger$ & $104 * \mathrm{ND} \dagger$ & $125 * \mathrm{ND} \dagger$ & $192^{*} \mathrm{ND} \dagger$ \\
\hline Diterpene 2 & $\begin{aligned} 910 & \pm 8.9 * 1516 \\
& \pm 13 \dagger\end{aligned}$ & $\begin{array}{c}1056 \pm 6.9 * 1123 \\
\pm 9 \dagger\end{array}$ & $\begin{aligned} 1385 & \pm 9.5^{*} 1918 \\
& \pm 11 \dagger\end{aligned}$ & $120 \pm 5.7 * \mathrm{~N} \dagger$ & $7.5 * \mathrm{ND} \dagger$ & $8.8 * \mathrm{ND} \dagger$ & $11.5 * \mathrm{ND} \dagger$ \\
\hline
\end{tabular}

Standard compound and diterpenes from C. cervicornis $\mathrm{CC}_{50}$ in Vero cell ${ }^{*}$ and MDBK cell $\dagger(\mu \mathrm{M}) \mathrm{HHV}-1^{*}$ and BoHV-5† EC ${ }_{50}(\mu \mathrm{M}) \mathrm{SI}\left(\mathrm{HHV}-1^{*}\right.$ and BoHV-5†)

Human alphaherpesvirus 1 (KOS). Bovine alphaherpesvirus 5 (BoHV-5RJ42/01). The $\mathrm{CC}_{50} * / \dagger$ is the compound concentration required to reduce the number of viable Vero and MDBK cells by $50 \% ; \mathrm{EC}_{50} * / \dagger$ is the effective concentration required to reduce HHV-1 KOS and BoHV-5RJ42/01 yield by $50 \%$ in Vero and MDBK cells. Selectivity Index (SI*/ $\dagger$ ) was defined as the ratio between $\mathrm{CC}_{50} / \mathrm{EC}_{50}$ ratio and represents the safety for in vitro assay. [3-(4,5-dimethylthiazol-2yl)-2,5diphenyl tetrazolium bromide] (MTT). Neutral red (NR). Violet crystal (VC). Micromolar $(\mu \mathrm{M})$.
Not inhibit BoHV-5RJ42/01 yield (N). Not determined (ND). $\mathrm{CC}_{50}{ }^{*} /$ $\dagger$ and $\mathrm{EC}_{50} * / \dagger$ data represent the average values $( \pm$ standard deviations) of at least three independent experiments. Acyclovir was used as positive control. Compounds diterpenes 1 and 2 were not able to inhibit HHV-1 KOS and BoHV-5RJ42/01 specific receptors attachment on Vero and MDBK cell respectively but they were able to interact directly with HHV-1 KOS and BoHV-5RJ42/01 particles reducing their infectivity (Figure2).
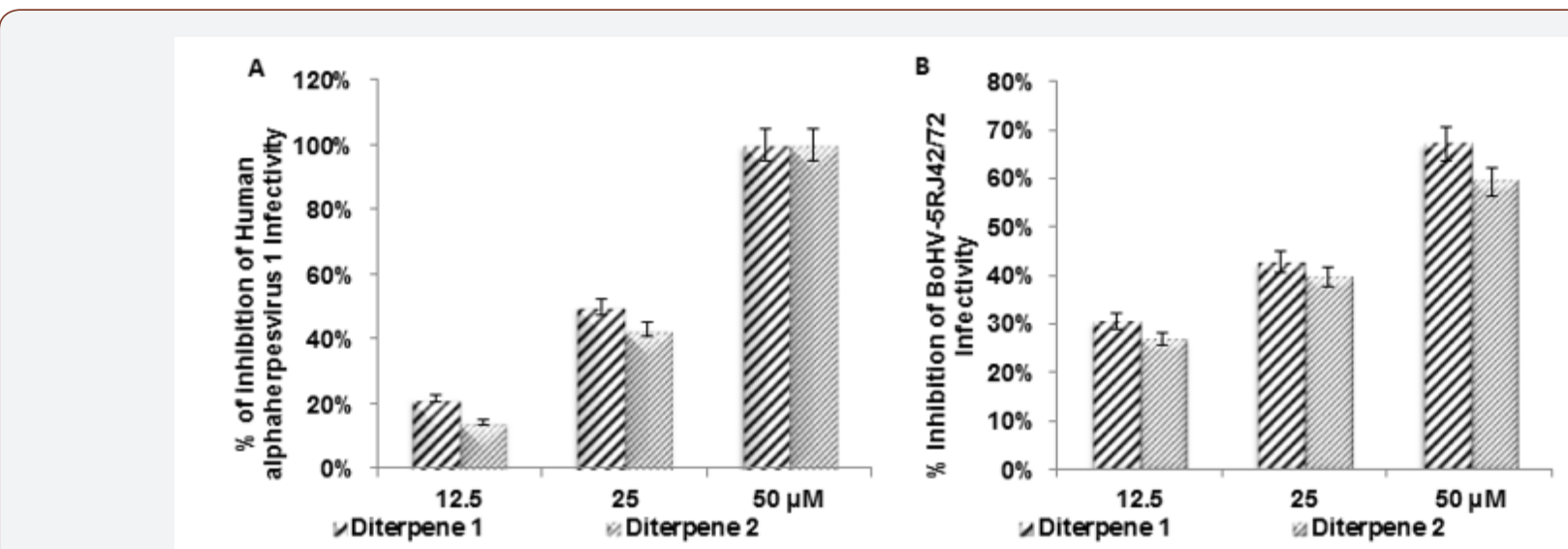

Figure 2: Reduction of infectivity of the HHV-1 KOS (A) and BoHV-RJ42/015 (B) due their direct interaction with diterpenes 1 and 2.

\section{Discussion}

Marine organisms are known producers of pharmacological and antiviral agents and may provide unlimited biological resources for the production of therapeutic compounds against viral infections in humans. Extracted compounds from seaweeds have in vitro and/or in vivo activity against a wide range of viruses, including Human alphaherpesvirus 1, Human alphaherpesvirus 2 [29], Bovine alphaherpesvirus-5 [28], Equine alphaherpesvirus 1 [30] and Bovine viral diarrhea virus [31] and human deficiency viruses [23]. The Human alphaherpesvirus 1and Bovine alphaherpesvirus-5 are important pathogen for humans and bovine respectively and discovery effective antiherpetic chemotherapeutic without adverse effects is of great interest of researchers.

Vallim, Juliana [22] evaluate the cytotoxicity and antiviral activity against HHV-1of two hydroxylated diterpenes in Vero cell and they were not cytotoxic and had good antiviral activity. Our study evaluated cell cytotoxicity by a multiparametric assay (MTT, neutral red and violet crystal) diterpene 1 containing two acetyl groups was slightly cytotoxic to Vero cell by MTT and neutral red and violet crystal assay suggesting low toxic effect of compounds in mitochondria activity, lysosome membrane and nuclear integrity. Although the diterpene 1 showed a little more cytotoxic compound 
to Vero cell it inhibited HHV-1 KOS with low $\mathrm{EC}_{50}$ and high SI value. The SI determines the degree of security of the drugs administration and take into in consideration the relation between $\mathrm{CC}_{50}$ and $\mathrm{EC}_{50}$ value. Diterpene 1 and 2 were not cytotoxic to MDBK cell but both compounds did not inhibit BoHV-5RJ42/01 production in MDBK cell. The HHV-1 KOS and BoHV-5RJ42/01 belong of Herpesviridae family replicate in susceptible and permissive cell so diterpene 1 and 2 were not able to break this permissibility of the MDBK cell to BoHV-5RJ42/01 tested.

Previously our group related hydroxylated diterpenes were not able to interact directly with HHV-1 particle and inactivate it [22]. On the other hand, we are showing that acetylated diterpenes 1 and 2 interacted directly with HHV-1 KOS and BoHV-5RJ42/01 particles reducing their infectivity (virucidal effect) to Vero and MDBK cells so we speculate the possibility of these compounds to be used as microbicides in treatment of HHV-1 and BoHV-5 in human and bovine clinical trials respectively. Previous relates by researcher of our group showed the ability of diterpenes 1 and 2 to inhibit the infectivity of human immunodeficiency virus 1 (Barros et al., 2015). It is important highlight that both compounds did not inhibit HHV1KOS and BoHV-5RJ42/01 attachment and virus penetration. They did not block HHV-1 KOS and BoHV-5RJ42/01 interaction with specific receptor on Vero and MDBK cells during attachment assay in untreated cell by compounds. Maybe it is due the high affinity between virus and their receptors. Diterpenes 1 and 2 were not able to interact with virus specific receptor interfering with HHV-1 KOS and BoHV-5RJ42/01 attachment on pretreated Vero and MDBK cells with these compounds.

Our findings relating the antiviral activity $\left(\mathrm{EC}_{50}\right)$ and SI values lead us to suggest diterpene 1 as the most promising drugs to HHV-1 than diterpene 2 but both compounds at $50 \mu \mathrm{M}$ were able to inactivate HHV1 around 100\% and BoHV-5RJ42/01 particles around $60 \%$ Thus, they will be good candidates for effective antiHHV-1 and BoHV-5 microbicide to human and bovine as strategies to prevent HHV-1 and BoHV-5 during sexual contact. They will be used in bull semen treatment before bovine artificial insemination due to their high $\mathrm{CC}_{50}$ value to MDBK cell. Nevertheless further analyses are underway to better understand the in vitro antiviral mechanism of these compounds and to define the precise in vitro antiviral correlating between molecular structure and bioactivity.

\section{Acknowledgments}

This work was supported by National Council for Scientific and Technological Development (CNPq), Coordination for the Improvement of Higher Education Personnel (CAPES) and Rio de Janeiro State Research Support Foundation (FAPERJ).

\section{Conflicts of Interest}

No conflicts of interest.

\section{References}

1. (2017) ICTV International Committee on Taxonomy of Viruses.

2. Roizman B, Knipe D, Whitley R (2007) Herpes simplex viruses, Fields virology 2: 2501-2601.
3. Carrillo BJ, Ambrogi A, Schudel AA, Vazquez M, Dahme E, et al. (1983) Meningoencephalitis caused by IBR Virus in Calves in Argentina*. Zentralblatt fur Veterinaermedizin Reihe B 30(5): 327-332.

4. French E (1962) A specific virus encephalitis in calves: isolation and characterization of the causal agent. Australian Veterinary Journal 38(4): 216-221.

5. Weiblen R, De Barros C, Canabarro T, Flores I (1989) Bovine meningoencephalitis from IBR virus. Veterinary Record 124(25): 666667.

6. Pinto AMV, Leite J, Romijn P, Silva R, Flores E, et al. (2014) A Retrospective search for bovine herpesvirus 5 (bohv-5) in the brain of cattle affected by neurological disease in rio de janeiro state. virus reviews \& research 19(2): 3 .

7. Schudel AA, Carrillo BJ, Wyler R, Metzler A (1986) Infections of Calves with Antigenic Variants of Bovine Herpesvirus 1 (BHV-1) and Neurological Disease. Journal of Veterinary Medicine, Series B 33(4): 303-310.

8. Oliveira M, Campos F, Dias M, Velho F, Freneau G, et al. (2011) Detection of bovine herpesvirus 1 and 5 in semen from Brazilian bulls. Theriogenology 75(6): 1139-1145.

9. Silva Frade C, Gameiro R, Martins A, Cardoso T (2010) Apoptotic and developmental effects of bovine Herpesvirus type- 5 infection on in vitro-produced bovine embryos. Theriogenology 74(7): 1296-1303.

10. Silva Frade C, Martins A, Borsanelli A, Cardoso T (2010) Effects of bovine Herpesvirus Type 5 on development of in vitro-produced bovine embryos. Theriogenology 73(3): 324-331.

11. Kim SK, Van Ta Q (2011) Potential beneficial effects of marine algal sterols on human health. Advances in food and nutrition research 64: 191-198.

12. Falcão C, Széchy MTMd (2005) Changes in shallow phytobenthic assemblages in southeastern Brazil, following the replacement of Sargassum vulgare (Phaeophyta) by Caulerpa scalpelliformis (Chlorophyta). Botanica Marina 48(3): 208-217.

13. Kelecom A, Teixeira VL (1988) Dolastane diterpenes from the marine brown alga Dictyota cervicornis. Phytochemistry 27(9): 2907-2909.

14. Teixeira V, Tomassini T, Kelecom A (1986) Cervicol, a further secodolastane diterpene from the marine brown alga Dictyota cervicornis Kützing (Phaeophyceae, Dictyotaceae). Bulletin des Societes Chimiques Belges 95(4): 263-268.

15. Teixeira VL, Tomassini T, Fleury BG, Kelecom A (1986) Dolastane and Secodolastane Diterpenes from the Marine Brown Alga, Dictyota cericornis. Journal of natural products 49(4): 570-575.

16. Aline Santos de O, Cavalcanti DN, Bianco EM, Joel De Paula, Pereira $\mathrm{RC}$, et al. (2008) Chemical composition of diterpenes from the brown alga Canistrocarpus cervicornis (Dictyotaceae, Phaeophyceae). Natural Product Communications 3(9): 1469-1472.

17. De Paula JC, de Gusmão Pedrini A, Pinheiro MD, Pereira RC, Teixeira VL (2001) Chemical similarity between the brown algae Dictyota cervicornis and D. pardalis (Dictyotales, Phaeophyta). Biochemical systematics and ecology 29(4): 425-427.

18. Bianco ÉM, Rogers R, Teixeira VL, Pereira RC (2009) Antifoulant diterpenes produced by the brown seaweed Canistrocarpus cervicornis. Journal of applied phycology 21(3): 341-346.

19. Bianco ÉM, Teixeira VL, Pereira RC (2010) Chemical defenses of the tropical marine seaweed Canistrocarpus cervicornis against herbivory by sea urchin. Brazilian Journal of Oceanography 58(3): 213-218.

20. Moura LDA, Sanchez EF, Bianco ÉM, Pereira RC, Teixeira VL, et al. (2011) Antiophidian properties of a dolastane diterpene isolated from the marine brown alga Canistrocarpus cervicornis. Biomedicine \& Preventive Nutrition 1(1): 61-66.

21. Santos AOd, Britta EA, Bianco EM, Ueda Nakamura T, Pereira RC, et al. (2011) 4-Acetoxydolastane diterpene from the Brazilian brown alga Canistrocarpus cervicornis as antileishmanial agent. Marine drugs 9(11): 2369-2383. 
22. Vallim MA, Juliana EB, Diana N, Cavalcanti o, Joel CD-P, et al. (2010) In vitro antiviral activity of diterpenes isolated from the Brazilian brown alga Canistrocarpus cervicornis. Journal of Medicinal Plants Research 4(22): 2379-2382.

23. Barros CdS, Cirne Santos CC, Garrido V, Barcelos I, Stephens PRS, et al. (2015) Anti-HIV-1 activity of compounds derived from marine alga Canistrocarpus cervicornis. Journal of Applied Phycology 1-5.

24. Cheng HY, Lin TC, Yang CM, Wang KC, Lin LT, et al. (2004) Putranjivain A from Euphorbia jolkini inhibits both virus entry and late stage replication of herpes simplex virus type 2 in vitro. Journal of Antimicrobial Chemotherapy 53(4): 577-583.

25. Mosmann T (1983) Rapid colorimetric assay for cellular growth and survival: application to proliferation and cytotoxicity assays. Journal of immunological methods 65(1): 55-63.

26. Fautz R, Husein B, Hechenberger C (1991) Application of the neutral red assay (NR assay) to monolayer cultures of primary hepatocytes: rapid colorimetric viability determination for the unscheduled DNA synthesis test (UDS). Mutation Research/Environmental Mutagenesis and Related Subjects 253(2): 173-179.
27. Saotome K, Morita H, Umeda M (1989) Cytotoxicity test with simplified crystal violet staining method using microtitre plates and its application to injection drugs. Toxicology in vitro 3(4): 317-321.

28. Pinto AMV, Leite JPG, Neves AP, da Silva GB, Vargas MD, et al. (2014) Synthetic amino-methyl-naphtho-quinones inhibit the in vitro replication of bovine herpesvirus 5. Archives of virology 159(7): 18271833.

29. Yasuhara Bell J, Yang Y, Barlow R, Trapido Rosenthal H, Lu Y (2010) In vitro evaluation of marine-microorganism extracts for anti-viral activity. Virology journal 7: 182.

30. Marinho RDSS, Ramos CJB, Leite JPG, Teixeira VL, Izabel Paixão, et al. (2017) Antiviral activity of 7-keto-stigmasterol obtained from green Antarctic algae Prasiola crispa against equine herpesvirus 1. Journal of applied phycology 29(1): 555-562.

31. Pinto AMV, Leite JPG, Ferreira WJ, Cavalcanti DN, Villaça RC, et al. (2012) Marine natural seaweed products as potential antiviral drugs against bovine viral diarrhea virus. Brazilian Journal of Pharmacognosy 22(4): 813-817. 